\title{
Fashion Communication in Asia: Participant Observation and Qualitative Interview with Media Personnel at MILK X Monthly
}

\author{
Tommy Ho-lun TSE
}

\begin{abstract}
The presentation, extracted from the author's doctoral research named 'This Is Not an LV Bag - The Simulacra of Fashion in and beyond the Media Business in Hong Kong and Mainland China,' investigates how global fashion brands and Hong Kong print media appropriate and negotiate the meaning of 'fashion' and its vicissitudes in and through the process of marketing communication in the local context. The researcher played the role of participant observer in the editorial team of high fashion magazine MILKX Monthly (2011). Through the process, the author partook in the realistic work environment and daily routines, and examined the interactions of fashion media workers; befriended and dialogued with eight internal co-workers from ad sales executives to editors, from (advertorial) copywriters to graphic designers; connected and interviewed other external fashion media workers in the Asian context, altogether help the researcher acquire valuable insights to outline the contemporary fashion media landscape in conjunction with diverse academic theorisations of fashion and fashion communication. The interviewed fashion media personnel come from an array of cultural, experiential and organisational backgrounds, which contributes to the comprehensiveness and firsthandedness of this case study. The transcribed interviews have been thematically coded and analysed. The interviewee's position within the media organisation, understanding of the publication's positioning and intended portrayal of fashion, perception of the power of various fashion media in defining 'what fashion is' were inquired and investigated. The result shows that, in the production process of textual and graphical/visual fashion, various internal and external negotiations of how to demonstrate the appropriate fashion messages were frequently staged. Such process narrowed down, redefined and consolidated a wide range of fashion meanings, followed by the final representations of such in specific manner. The findings validate the 'exploitative and creative' nature of fashion communication theorised in the Western academic discourse.
\end{abstract}

Key Words: Fashion communication, fashion media, fashion journalist, fashion personnel, fashion theory, participant observation, Hong Kong, Asia.

$* * * * *$

\section{Overview}

Fashion is ubiquitous, and it plays a significant role in the contemporary global market, in the creative industries and in urban social space. In the realms of art, history, philosophy and cultural studies, however, fashion is often regarded as a 
subaltern, peripheral or even unorthodox topic. Hence, this study aimed at remapping the relationships among the interdisciplinary and conflicting notions of fashion, determining which and how fashion theories are applicable to the real fashion industry in a specific place at a particular time, apprehending the nuanced mechanisms involved, and seeking to create a substantial case for the social construction of fashion. In the literature review, two broad camps of debating views towards fashion are discerned. In the critical Marxist camp, Marx, ${ }^{1}$ Veblen, ${ }^{2}$ Adorno, ${ }^{3}$ Baudrillard, ${ }^{4}$ Barthes, ${ }^{5}$ Derrida $^{6}$ and Bourdieu ${ }^{7}$ are among those who criticise fashion as a means of economic exploitation. They believed that the industry actively manipulates the illogical and empty fashion trends to cheat the public. Veblen and Bourdieu addressed fashion as a conspicuous vanity of the leisure class and a weapon in social position-taking. Both highlighted how fashion exclusively privileges the bourgeois over what in their day was termed the working classes. ${ }^{8}$

In contrast, Wilson, ${ }^{9}$ Jobling, ${ }^{10}$ Barnard, ${ }^{11}$ Hall, ${ }^{12}$ Lipovetsky, ${ }^{13}$ Skov, ${ }^{14}$ Chevalier and Mazzalovo ${ }^{15}$ have more recently tried to go beyond the critical Marxist perspective, all proposing that fashion has social utility and involves multiple twists in its meanings throughout the complicated encoding and decoding processes. Wilson and Lipovetsky asserted that the fashion consumer/wearer can alter fashion meanings - it can serve as a creative activity and entertainment, and as a means to define human individuality and lessen the social distance between classes. ${ }^{16}$ Barthes and Jobling have highlighted the fashion media as fashion's mediator, generating its meanings. ${ }^{17}$ Skov, Chevalier and Mazzalovo claimed that the fashion creator/producer plays a major role in encoding fashionability. ${ }^{18}$ In Hall's and Barnard's view, the creator, the mediator and the wearer are all involved in negotiating fashion's meanings. ${ }^{19}$ Again, the above ideas will be adopted to test their validity in the real social setting through participant observation.

\section{Methodology}

The researcher served as a voluntary and unpaid junior fashion reporter with local high fashion monthly publication MILK $X$ Monthly (see Appendix) for three months. The work involved daily face-to-face interaction with other employees of the magazine, but also with other external members such as freelance photographers, models and fashion publicists. This enabled studying and analysing their styles of cooperation. Meanwhile, the data were also collected through the interviews with eight of MILK X Monthly's personnel who came from all four of the magazine's major teams - editorial, copywriting/project, design, and advertising sales. All the media workers have been given false names and their personal traits have been altered and displaced.

A key research question is whether fashion is, as the critical theorists suggest, purely an arbitrary, preemptive message controlled and imposed according to the 
preferences of fashion producers; or, as the pluralistic theorists assert, especially Barnard, is it negotiated through the process of fashion communication? Exploring it may provide insight into the power politics involved along the communication chain. This chapter investigates how MILK X Monthly and its personnel try to maintain and negotiate a specific set of fashion meanings in daily operations. Coded observation data and interview responses give an impression of the MILKX Monthly staff's vigorous negotiations with various internal and external parties.

\section{Negotiations in and beyond MILK X Monthly}

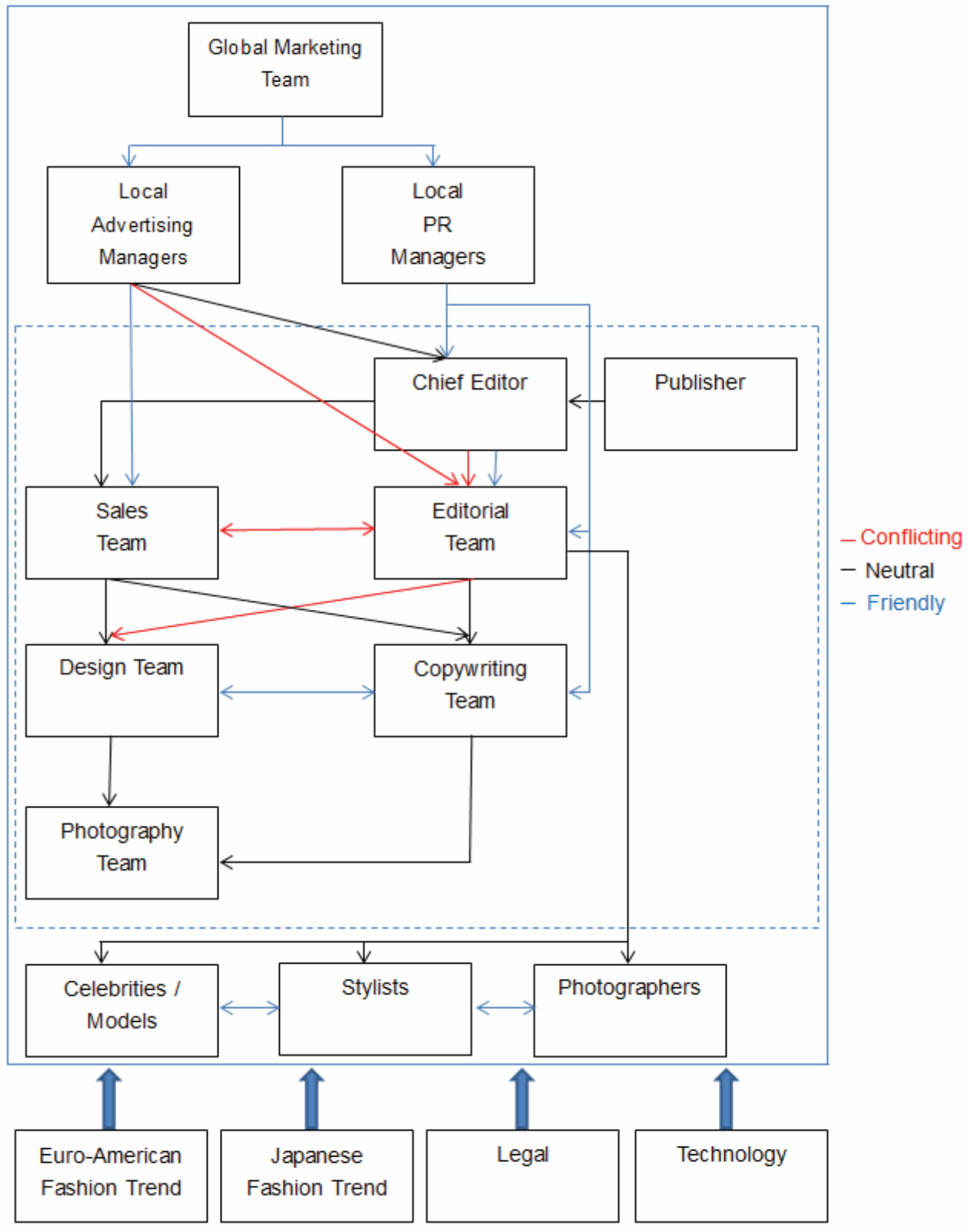

Image 1: Negotiations in and beyond MILK X Monthly 
A. Copywriting/Project Team

In the eyes of the journalists and designers, the copywriters worked in two teams simultaneously: advertising sales and editorial. They had difficulties in deciding which suggestion to follow and which way to go artistically. Senior copywriter Ginny said she had experienced many conflicts with the design team and the advertising sales team. She criticised the aesthetic sense of the in-house graphic designers. '[I]n many cases, these so-called designers...could totally mistake what you say...you even have to provide them guidelines for mixing and matching palettes and typography...The basic requirement of being a designer can be merely the technical software skills... [to collaborate with them] sometimes you need to spend even more time to solve the problem.' As for the advertising sales personnel, Ginny thought that they only focused on the sales perspective but were unaware of the reader's interests. They neglected the needs of readers and advocated hard-selling product shots and texts. All she could do was to tactfully convince the ad sales team and strike a balance between the demands of clients and magazine readers.

When copywriter Timothy was asked if he considered himself a fashion creator, he responded, '...it is not my role. For fashion editors, [theoretically] they are endowed with the right to choose whatever fashion items they prefer to introduce, like now they consider this item chic and then declare these are the trendy items of this season or those products will become hits in the next season. It would be difficult in my position [to do so]...In the end I still take the needs of our client as my first priority.' After his 2-year experience at MILK X Monthly, Timothy understood that many items introduced by the fashion magazines were in fact not genuinely the editors' choices. More often, the 'editorial content' is advertorials and sponsored features, and there is little genuine editorial content left. Timothy had discerned that even fashion reporters chose to feature some items, they might incline to feature their favourite clients. Such editorial content might even be used by the advertising sales team as a reference or included in a media sales kit tailored for the client for the sake of selling advertising. 'In the end it's about increasing ad sales. Thus I personally think that [fashion] magazines are not neutral when portraying the fashion trends...All about money...Maybe other media companies are not like that, or [maybe] similar.'

\section{B. Design Team}

According to culture and lifestyle reporter Kim's experience, the graphic design team was usually the passive party in fashion encoding. Even when the graphic designers applied their aesthetic judgment and recommended graphical adjustments, they mainly followed the editorial team's layout brief. Junior designer Cammy supposed even if the fashion media might aspire to insist on their viewpoints, they would have to give in eventually. 'We cannot hold to our standpoints; [the clients] always override us... What we can say is, "Alright, 


\title{
Fashion Communication in Asia: Participant Observation and Qualitative Interview with Media Personnel at MILK X Monthly
}

\author{
Tommy Ho-lun TSE
}

\begin{abstract}
The presentation, extracted from the author's doctoral research named 'This Is Not an LV Bag - The Simulacra of Fashion in and beyond the Media Business in Hong Kong and Mainland China,' investigates how global fashion brands and Hong Kong print media appropriate and negotiate the meaning of 'fashion' and its vicissitudes in and through the process of marketing communication in the local context. The researcher played the role of participant observer in the editorial team of high fashion magazine MILKX Monthly (2011). Through the process, the author partook in the realistic work environment and daily routines, and examined the interactions of fashion media workers; befriended and dialogued with eight internal co-workers from ad sales executives to editors, from (advertorial) copywriters to graphic designers; connected and interviewed other external fashion media workers in the Asian context, altogether help the researcher acquire valuable insights to outline the contemporary fashion media landscape in conjunction with diverse academic theorisations of fashion and fashion communication. The interviewed fashion media personnel come from an array of cultural, experiential and organisational backgrounds, which contributes to the comprehensiveness and firsthandedness of this case study. The transcribed interviews have been thematically coded and analysed. The interviewee's position within the media organisation, understanding of the publication's positioning and intended portrayal of fashion, perception of the power of various fashion media in defining 'what fashion is' were inquired and investigated. The result shows that, in the production process of textual and graphical/visual fashion, various internal and external negotiations of how to demonstrate the appropriate fashion messages were frequently staged. Such process narrowed down, redefined and consolidated a wide range of fashion meanings, followed by the final representations of such in specific manner. The findings validate the 'exploitative and creative' nature of fashion communication theorised in the Western academic discourse.
\end{abstract}

Key Words: Fashion communication, fashion media, fashion journalist, fashion personnel, fashion theory, participant observation, Hong Kong, Asia.

$* * * * *$

\section{Overview}

Fashion is ubiquitous, and it plays a significant role in the contemporary global market, in the creative industries and in urban social space. In the realms of art, history, philosophy and cultural studies, however, fashion is often regarded as a 
subaltern, peripheral or even unorthodox topic. Hence, this study aimed at remapping the relationships among the interdisciplinary and conflicting notions of fashion, determining which and how fashion theories are applicable to the real fashion industry in a specific place at a particular time, apprehending the nuanced mechanisms involved, and seeking to create a substantial case for the social construction of fashion. In the literature review, two broad camps of debating views towards fashion are discerned. In the critical Marxist camp, Marx, ${ }^{1}$ Veblen, ${ }^{2}$ Adorno, ${ }^{3}$ Baudrillard, ${ }^{4}$ Barthes, ${ }^{5}$ Derrida $^{6}$ and Bourdieu ${ }^{7}$ are among those who criticise fashion as a means of economic exploitation. They believed that the industry actively manipulates the illogical and empty fashion trends to cheat the public. Veblen and Bourdieu addressed fashion as a conspicuous vanity of the leisure class and a weapon in social position-taking. Both highlighted how fashion exclusively privileges the bourgeois over what in their day was termed the working classes. ${ }^{8}$

In contrast, Wilson, ${ }^{9}$ Jobling, ${ }^{10}$ Barnard, ${ }^{11}$ Hall, ${ }^{12}$ Lipovetsky, ${ }^{13}$ Skov, ${ }^{14}$ Chevalier and Mazzalovo ${ }^{15}$ have more recently tried to go beyond the critical Marxist perspective, all proposing that fashion has social utility and involves multiple twists in its meanings throughout the complicated encoding and decoding processes. Wilson and Lipovetsky asserted that the fashion consumer/wearer can alter fashion meanings - it can serve as a creative activity and entertainment, and as a means to define human individuality and lessen the social distance between classes. ${ }^{16}$ Barthes and Jobling have highlighted the fashion media as fashion's mediator, generating its meanings. ${ }^{17}$ Skov, Chevalier and Mazzalovo claimed that the fashion creator/producer plays a major role in encoding fashionability. ${ }^{18}$ In Hall's and Barnard's view, the creator, the mediator and the wearer are all involved in negotiating fashion's meanings. ${ }^{19}$ Again, the above ideas will be adopted to test their validity in the real social setting through participant observation.

\section{Methodology}

The researcher served as a voluntary and unpaid junior fashion reporter with local high fashion monthly publication MILK $X$ Monthly (see Appendix) for three months. The work involved daily face-to-face interaction with other employees of the magazine, but also with other external members such as freelance photographers, models and fashion publicists. This enabled studying and analysing their styles of cooperation. Meanwhile, the data were also collected through the interviews with eight of MILK X Monthly's personnel who came from all four of the magazine's major teams - editorial, copywriting/project, design, and advertising sales. All the media workers have been given false names and their personal traits have been altered and displaced.

A key research question is whether fashion is, as the critical theorists suggest, purely an arbitrary, preemptive message controlled and imposed according to the 
preferences of fashion producers; or, as the pluralistic theorists assert, especially Barnard, is it negotiated through the process of fashion communication? Exploring it may provide insight into the power politics involved along the communication chain. This chapter investigates how MILK X Monthly and its personnel try to maintain and negotiate a specific set of fashion meanings in daily operations. Coded observation data and interview responses give an impression of the MILKX Monthly staff's vigorous negotiations with various internal and external parties.

\section{Negotiations in and beyond MILK X Monthly}

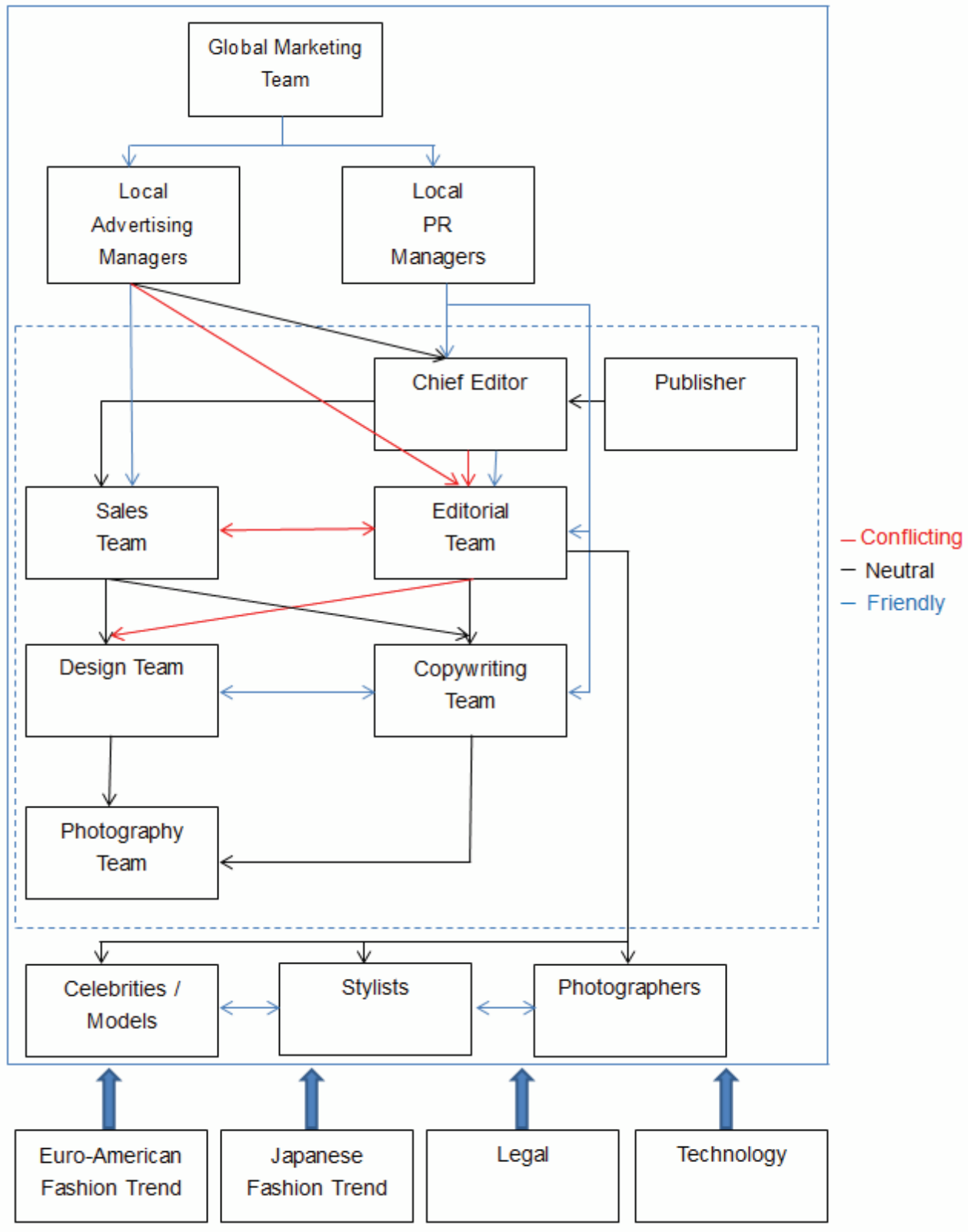

Image 1: Negotiations in and beyond MILK X Monthly 
A. Copywriting/Project Team

In the eyes of the journalists and designers, the copywriters worked in two teams simultaneously: advertising sales and editorial. They had difficulties in deciding which suggestion to follow and which way to go artistically. Senior copywriter Ginny said she had experienced many conflicts with the design team and the advertising sales team. She criticised the aesthetic sense of the in-house graphic designers. '[I]n many cases, these so-called designers...could totally mistake what you say...you even have to provide them guidelines for mixing and matching palettes and typography...The basic requirement of being a designer can be merely the technical software skills... [to collaborate with them] sometimes you need to spend even more time to solve the problem.' As for the advertising sales personnel, Ginny thought that they only focused on the sales perspective but were unaware of the reader's interests. They neglected the needs of readers and advocated hard-selling product shots and texts. All she could do was to tactfully convince the ad sales team and strike a balance between the demands of clients and magazine readers.

When copywriter Timothy was asked if he considered himself a fashion creator, he responded, '...it is not my role. For fashion editors, [theoretically] they are endowed with the right to choose whatever fashion items they prefer to introduce, like now they consider this item chic and then declare these are the trendy items of this season or those products will become hits in the next season. It would be difficult in my position [to do so]...In the end I still take the needs of our client as my first priority.' After his 2-year experience at MILK X Monthly, Timothy understood that many items introduced by the fashion magazines were in fact not genuinely the editors' choices. More often, the 'editorial content' is advertorials and sponsored features, and there is little genuine editorial content left. Timothy had discerned that even fashion reporters chose to feature some items, they might incline to feature their favourite clients. Such editorial content might even be used by the advertising sales team as a reference or included in a media sales kit tailored for the client for the sake of selling advertising. 'In the end it's about increasing ad sales. Thus I personally think that [fashion] magazines are not neutral when portraying the fashion trends...All about money...Maybe other media companies are not like that, or [maybe] similar.'

\section{B. Design Team}

According to culture and lifestyle reporter Kim's experience, the graphic design team was usually the passive party in fashion encoding. Even when the graphic designers applied their aesthetic judgment and recommended graphical adjustments, they mainly followed the editorial team's layout brief. Junior designer Cammy supposed even if the fashion media might aspire to insist on their viewpoints, they would have to give in eventually. 'We cannot hold to our standpoints; [the clients] always override us... What we can say is, "Alright, 
whatever they want we will follow." That's the way things are.' She described collaborating with an American outdoors wear brand. 'I tried to propose several graphical ideas to them. Eventually they rejected them all and even asked "Why don't you just follow our [in-house] designer's layout?" Cammy did not realize that the magazine had to replicate the client's sample layout faithfully. Most disapprovingly, she recounted the client's criticism in a sarcastic tone. 'Our designer worked so hard to create the layout. Why don't you just follow?' She was furious and did not understand why the brand's marketers did not place a print advertisement right away if the in-house designer had already fixed everything. 'They pay the bill and get what they want...Because of that we [the design team] had a meeting with the chief editor, and his comment was it's simply a waste of time so we should just give in...See, you can never, ever express your creative ideas, because they [the client] have already got one.' When asked if there was space for negotiation, Cammy exclaimed, 'We can't even contact the client directly, the advertising sales team does... When we told [the ad sales team] we really didn't like the proposed styling and graphic design as it really doesn't match MILK X Monthly's aesthetic style, they promised they would pass the message to the client, but they never did.' Cammy mimicked the consoling voice of the ad salesmen, 'Okay, don't worry. We'll try our best to stand by you,' but she was disappointed every time when she received the subsequent response from the client.

Designer Mag quoted another commercial project with a major Hong Kong jewellery brand. 'We mostly had [conflicts] with the sales team... It was just due to our different standpoints. I feel that they will stand by the clients' side and try not to offend them...For the work schedule we are even more antagonistic. The designer knew very well that brands like ABC Jewellery, even if they were not unethical at all, had what Mag called a 'corny and outdated' brand image far from the fashion image to which MILK X Monthly aspired.' 'They just want to infinitely enlarge [the image of] their classic 'gold plaque' engraved with a dragon on the page...to the extent it [the layout] no longer looks like an editorial piece, not even a print ad, but an excessively hard-selling advertising poster... Whenever we reach that point, we will be in sheer despair.' Mag concluded that flexibility in encoding fashion only comes when it is offered by the client, and this rarely happens.

\section{Editorial Team}

It was rather noticeable that the chief editor Cello took a dominant role in determining the magazine's direction, monitoring every MILK $X$ staff's work schedule as well as pushing them to meet editorial deadlines and advertising sales targets. He was at once the chief editor, chief designer and head of advertising sales. Most MILK X Monthly staff admired Cello's ability and expressed their strong faith in his judgment. 
In the daily work at MILKX Monthly, Cello elucidated the practical difficulties in the external communication process, such as featuring an 'inside story' about a fashion brand. Cello repeatedly reminded the observer how easily the editorial team might trespass on the untouchable territory of the fashion brands. The client's marketing and communication team is only a tiny little gear of the giant fashion industry and unauthorised to speak on behalf of the brand's creative direction. Everything has to be controlled and monitored carefully because a few incorrect messages may potentially undermine or even ruin the consistently communicated brand identity. In Cello's view, uncertain individual opinions should be silenced and eradicated in most cases, such as the marketers' personal fashion tastes and favourite brands.

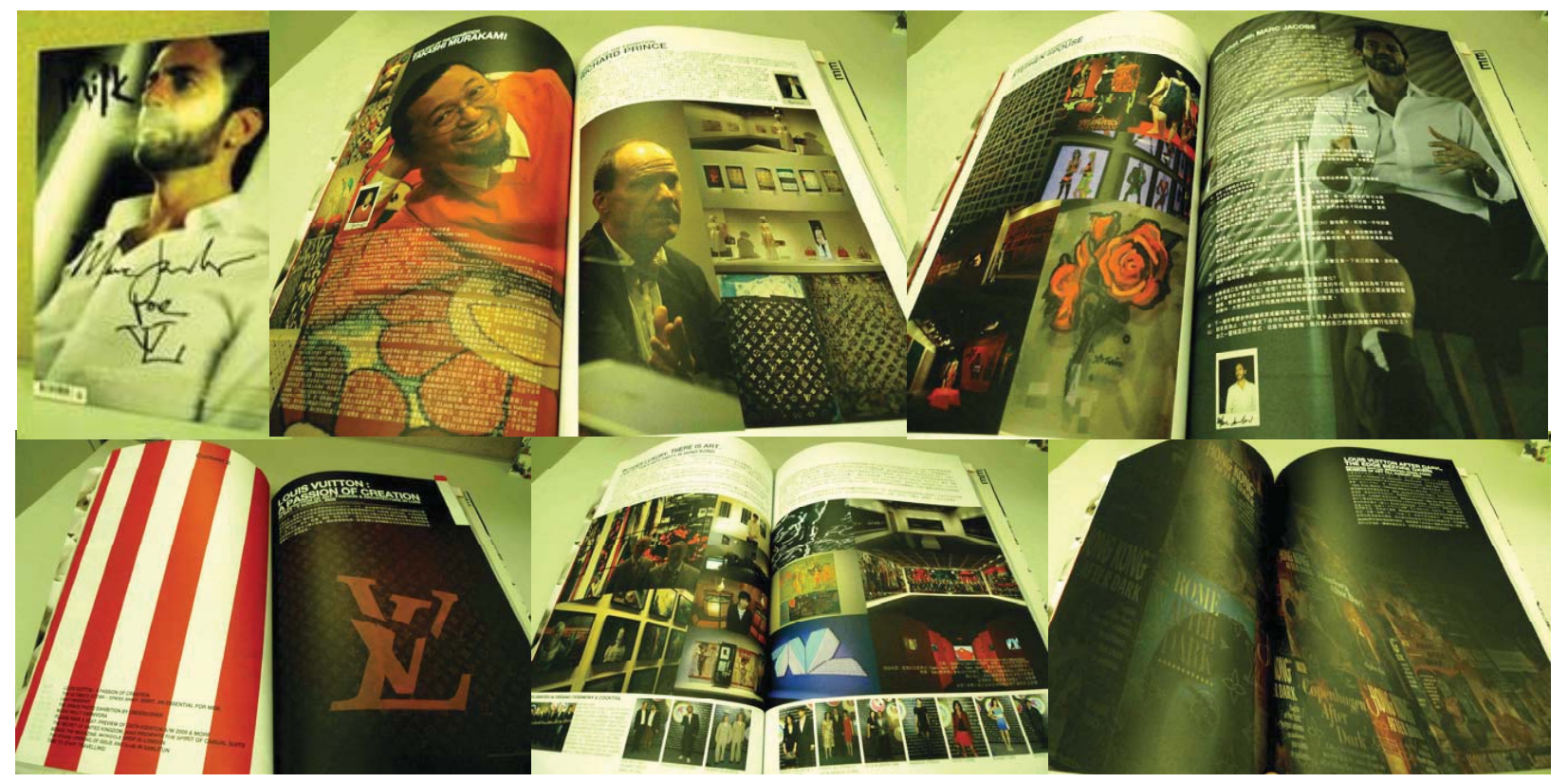

Image 2: MILKX Monthly Issue 34. (C) 2009/ Featuring Marc Jacobs, Former Creative Director of Louis Vuitton.

So who, then, could speak for a fashion brand to the press? 'Only those deified fashion figures,' usually the legendary head designer or creative director of a fashion brand, has the right to express their ideas, such as Karl Lagerfeld and Marc Jacobs (see Imagde 1). In Cello's experience, the local team was even more powerless than the head-office team. They acted as an order-taker who might not necessarily know the original or authentic meanings of a new season's fashion collection and shop window design. That underlay his discouraging the editorial staff from interviewing local office representatives in hope of getting into the heart of a fashion brand and exploring the true meanings beneath various manifestations of fashion. When fashion publicists are asked speak on behalf of their brands, no matter on what topic, many become very nervous and immediately say, 'We would like to seek for permission from the head office' - and that already means 'no' 
according to Cello. This caution is common to all the prominent brands such as Louis Vuitton, Gucci, Chanel and Prada. Even if they consider a media interview, their publicists will first ask what other brands have promised to participate. They will also enquire about their interviewee's position in the organisation, the number of print pages involved, the questions to be asked and so forth, before promising to do the interview. They fear any unfavourable comparisons. Overall, a subconscious and internalised censorship system was observed among both the media gatekeepers and the fashion marketers.

However, the fashion PR executives also take initiatives to maintain positive relationships with fashion editors. They send seasonal greeting cards and regularly deliver new product samples for trial. Fashion editor Fei Fei and senior editor Tina regularly received expensive fashion products, cosmetics and skin care product samples from various brands. In Tina's case, she got too many of them each season and she herself could hardly use them all. It shows how fashion publicists strive to build rapport and influence fashion journalists to write good reviews of their products. Mag once said,

I feel that sometimes...the proposed editorial idea really depends on the relationship between the editors and fashion publicists... Maybe because the fashion editor personally doesn't like a fashion brand or its publicist, not so relevant to its level of fashionability or its products, so he or she will not feature it...Or if you accept a particular brand's sponsorship to attend its catwalk show during the [Paris or Milan] Fashion Week, naturally you have to offer the brand editorial support.

In a casual conversation, Fei Fei exposed her discontent about how Cello warned the editorial staff to be cautious when promising fashion marketers any specific amount of free editorial coverage. The number of pages allowed for editorials was tightened. 'The price of paper has risen significantly in the last two months due to the reduction of paper supply from Japan after the earthquake and tsunami...demand for paper from different magazines has increased...hence the price of printing paper from mainland China has been raised too.' Fei Fei insisted, however, that it is vital for a fashion magazine to contain an appropriate amount of non-advertorial content featuring a wide variety of fashion brands, as '[I]t could also help building relationships with fashion brands for potential collaboration and advertising sales in the future too.'

D. Sales Team

A comment from advertising sales manager Billy summarises the entire organisation's nuanced negotiation with the fashion advertisers. 'We successfully lead the readers to perceive fashion from various perspectives... Many other 
magazines...they take the materials from the fashion brands and directly present them [to the readers]...almost in a "straight-in-straight-out" mode....At MILK X Monthly we digest the information provided, and then we'll do a brand new photography session... adopt a new angle appropriate to the subject.'

Yet, Billy also admitted that he had encountered problems in cooperating with the editorial team in his daily work. 'I'm not familiar with the situation in other fashion magazine companies... [The fashion journalists] don't prefer handling these client-subsidized projects...this is a fundamental conflict...We are on many occasions not welcomed by the MILKX Monthly journalists.'

\section{Summary}

The observations at MILK X Monthly confirm that the process of fashion media communication frequently involves negotiation of meanings. Negotiation is about the priority, suitability and fashionability of various textual and visual messages, and it often emphasises economic factors rather than aesthetics. In such negotiations, power relations favour the major advertisers and global fashion conglomerates. Other social, cultural and interpretive factors, for instance the upcoming fashion trends, personal tastes and aesthetic sense, are involved primarily when fashion marketers and fashion media personnel negotiate about how best to encode the correct fashion meanings.

Most international fashion enterprises adopt a top-down, 'one-voice' approach in handling communications with the media. The fashion meanings set by the global headquarters, symbolising the 'authentic fashion,' is prioritised in most cases. Even though the Asia-Pacific region and greater China have become prominent markets for such firms in recent years, they still tightly control the dissemination of their messages to the Asian media. At the same time, a consensual self-censorship scheme operates, at least at MILKX Monthly. The editorial staffs are acutely conscious of the influence and interests of the magazine's advertisers. This was a tacit understanding rather than the subject of clear regulations.

The situation of traditional print media in Hong Kong, as elsewhere, is becoming more difficult and competitive. This leads to decreased editorial and creative autonomy and increased advertiser power in any negotiations. In Hong Kong, local fashion marketers have more power than the local fashion media, and the power of global fashion marketers supersedes that of the Asian marketers. International fashion brands, especially the successful ones, try their best to control not only the presentation of their advertising messages but also the editorial content that surrounds them.

In deciding the topics of their editorial content, the staff of MILK X Monthly, mainly the reporters and editors, can negotiate to a certain extent. The chief editor wielded the power of encoding fashionability. He tended to encourage the editorial team to include product articles. In these the journalists can express a more individualistic, mix-and-match aesthetic style, but very often they still follow the 
logic of commerce and emphasise potential advertisers' brands. This tends to leave Hong Kong photographers and designers little creative control over the notion of fashion. Even on occasions when the fashion editors and reporters think that the products from a brand 'look ugly' or 'are not very wearable,' they still must feature them if the brand is a significant advertiser. They understand that they do not want to irritate their sponsors, the influential communication managers.

Overall, both economic and cultural factors were involved in the process of negotiation in and beyond MILK X Monthly. Media personnel in the media organisation were conscious of the publication's commercial concerns for their editorial production. However, it did not guide all media workers' actual practices entirely through the encoding process in which creativity and improvisation were essential and inevitable. The official and preset fashion messages were commonly sent from the marketer to media, expecting to maintain a sense of consistency, though it was not always effective. A more complex mode of self-censorship on the fashion media's side, adaptation of social and cultural trends, as well as injection of personal tastes, aesthetic and cultural preferences were always involved. These echo Barnard's theorisation of fashion communication as a nonlinear and fluid process which interplays with various encoders and decoders, in addition to the social, cultural and economic concerns that influence them.

\section{Notes}

${ }^{1}$ Karl Marx, Capital, Volume I (London: Dent, 1967).

2 Thorstein Veblen, The Theory of The Leisure Class (New York: Macmillan, 1899).

${ }^{3}$ Theodor W. Adorno and Max Horkheimer, Dialectics of Enlightenment, trans. John Cumming (London: Verso, 1986).

${ }^{4}$ Jean Baudrillard, 'Fashion, or the Enchanting Spectacle of the Code', in Fashion Theory: A Reader, ed. Malcolm Barnard (London: Routledge, 2007).

${ }^{5}$ Roland Barthes, The Fashion System, trans. Matthew Ward and Richard Howard (Berkeley: University of California Press, 1990).

6 Jacques Derrida, of Grammatology, trans. Gayatri Chakravorty Spivak (Baltimore: Johns Hopkins University Press, 1976).

${ }^{7}$ Pierre Bourdieu, Sociology in Question (London: Sage, 1984).

${ }^{8}$ Veblen, Theory of Leisure Class, 52-54; Bourdieu, Sociology in Question.

${ }^{9}$ Elizabeth Wilson, Adorned in Dreams: Fashion and Modernity (London: Virago, 1985).

${ }^{10}$ Paul Jobling, Fashion Spreads: Word and Image in Fashion Photography since 1980 (Oxford: Berg, 1999).

${ }^{11}$ Malcolm Barnard, Fashion as Communication (London: Routledge, 1996). 
${ }^{12}$ Stuart Hall, 'Encoding/Decoding', in Media and Cultural Studies: Keyworks, eds. Meenakshi Gigi Durham and Douglas M. Kellner (Malden: Wiley-Blackwell, 2012).

${ }^{13}$ Gilles Lipovetsky, The Empire of Fashion: Dressing Modern Democracy (Princeton: Princeton University Press, 1994).

${ }^{14}$ Lise Skov, 'Hong Kong Fashion Designers as Cultural Intermediaries: Out of Global Garment Production', in Fashion: Critical Concepts in Media and Cultural Studies Volume III, ed. Malcolm Barnard (Abingdon, Oxon and New York: Routledge, 2012).

${ }^{15}$ Michel Chevalier and Gérald Mazzalovo, Luxury Brand Management: A World of Privilege (Singapore: John Wiley \& Sons (Asia), 2008).

${ }^{16}$ Wilson, Adorned in Dreams, 64-65; Lipovetsky, Empire of Fashion, 60-63.

${ }^{17}$ Barthes, The Fashion System, 277-278; Jobling, Fashion Spreads, 70-72 and 7678.

${ }^{18}$ Skov, 'Hong Kong Fashion Designers', 335-336; Chevalier and Mazzalovo, Luxury Brand Management, 81-84.

${ }^{19}$ Hall, 'Encoding/Decoding', 163-165; Barnard, Fashion as Communication, 7072.

\section{Bibliography}

Adorno, Theodor W., and Max Horkheimer. Dialectics of Enlightenment. Translated by John Cumming. London: Verso, 1986.

Barnard, Malcolm. Fashion as Communication. London: Routledge, 1996.

Barthes, Roland. The Fashion System. Translated by Matthew Ward, and Richard Howard. Berkeley: University of California Press, 1990.

Baudrillard, Jean. 'Fashion, or the Enchanting Spectacle of the Code'. In Fashion Theory: A Reader, edited by Malcolm Barnard, 462-474. London: Routledge, 2007.

Bourdieu, Pierre. Sociology in Question. London: Sage, 1984.

Chevalier, Michel, and Gérald Mazzalovo. Luxury Brand Management: A World of Privilege. Singapore: John Wiley \& Sons (Asia), 2008.

Derrida, Jacques. Of Grammatology. Translated by Gayatri Chakravorty Spivak. Baltimore: Johns Hopkins University Press, 1976. 
Hall, Stuart. 'Encoding/Decoding'. Media and Cultural Studies: Keyworks, edited by Meenakshi Gigi Durham, and Douglas M. Kellner, 163-173. Malden: WileyBlackwell, 2012.

Jobling, Paul. Fashion Spreads: Word and Image in Fashion Photography since 1980. Oxford: Berg, 1999.

Lipovetsky, Gilles. The Empire of Fashion: Dressing Modern Democracy. Princeton: Princeton University Press, 1994.

Marx, Karl. Capital, Volume I. London: Dent, 1967.

Skov, Lise. 'Hong Kong Fashion Designers as Cultural Intermediaries: Out of Global Garment Production'. In Fashion: Critical Concepts in Media and Cultural Studies Volume III, edited by Malcolm Barnard, 326-342. Abingdon, Oxon and New York: Routledge, 2012.

Veblen, Thorstein. The Theory of the Leisure Class. New York: Macmillan, 1899.

Wilson, Elizabeth. Adorned in Dreams: Fashion and Modernity. London: Virago, 1985.

Tommy Ho-lun TSE completed his MPhil degree in Comparative Literature at The University of Hong Kong, and his $\mathrm{PhD}$ degree in the Department of Sociology (HKU). He is currently a lecturer in the Department of Communication Studies, Hong Kong Baptist University. 


\section{Appendix}

Organisation Structure of MILK X Monthly

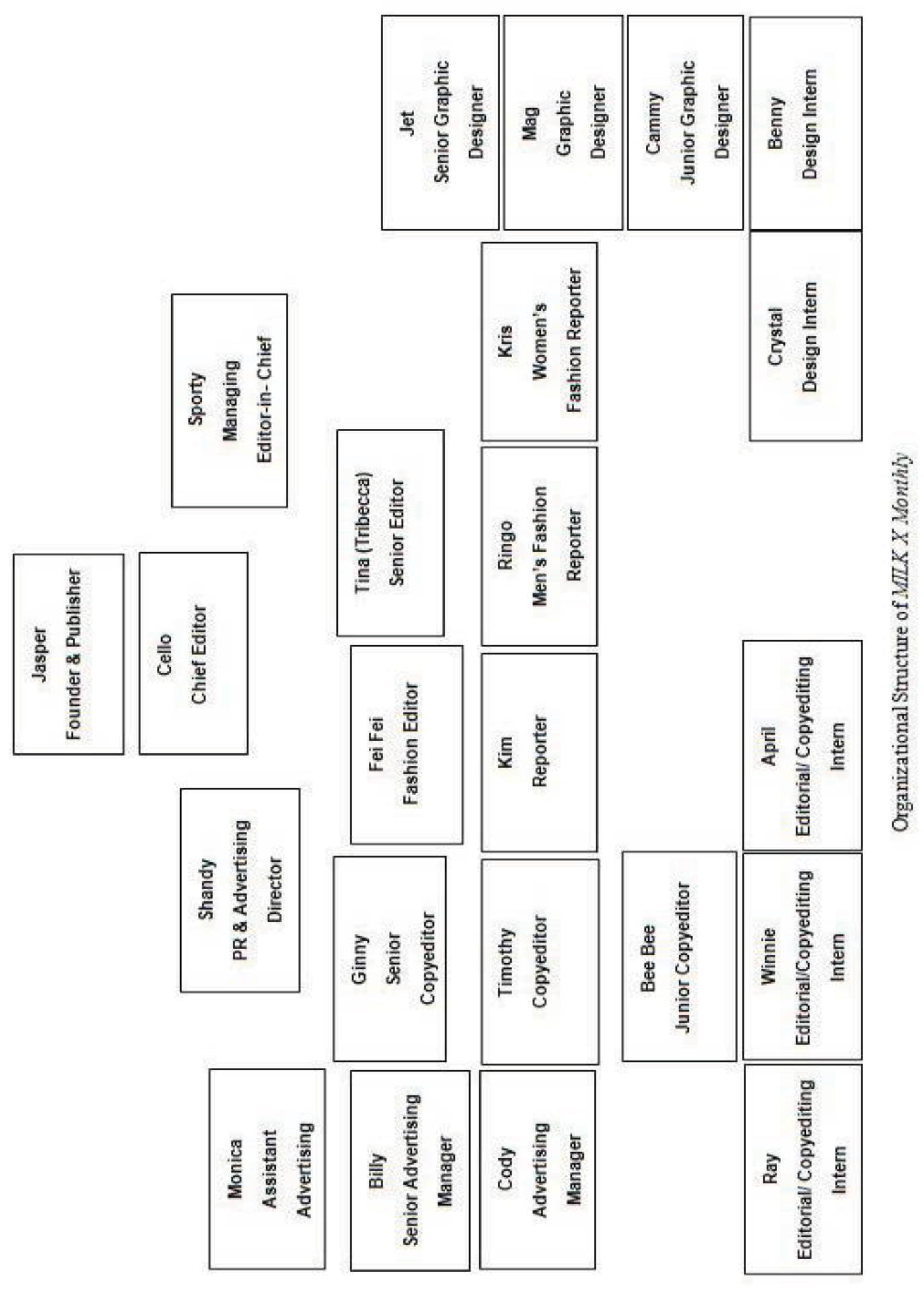

